\title{
Scottish Presbyterian Churches and Humanitarianism in the Interwar Middle East
}

\author{
Michael Marten
}

In this essay ${ }^{1}$ I seek to identify trends and patterns that offer us insights into ways of thinking about what the Scottish Presbyterian churches and their missionary organizations were doing in the European interwar period as they continued their long engagement in the Middle East, in particular focusing on Palestine. As they had been involved in the region since the $1840{ }^{2}{ }^{2}$ their presence meant they were reacting to changing circumstances, constantly in the process of seeking new ways to translate their understanding of Christianity in the region. This was not necessarily just about seeking new converts to Presbyterian Christianity, since although that would always be welcomed, their attempts to generate conversions were remarkably unsuccessful, as I have outlined elsewhere. ${ }^{3}$ Rather, over time they turned, as so many other Western church traditions did, into seeking to live a model or exemplary Christian life, as well as living out a civilizing mission that sought to modernize the world. This was, after all, a theme in the 1910 Edinburgh World Missionary Conference, demonstrated not least in the complex discussions around missionary-state relations. ${ }^{4}$

In reflecting on these contexts, it is important to be clear about the terms in use; all terminology is historically contingent, and so whilst contemporary scholars such as Michael Barnett define "humanitarianism" in ways that reflect

1 Early versions of this paper were presented at a workshop at Stirling University in December 2017, and at the Scottish Church History Society's conference in Glasgow in March 2018. I am grateful to participants at both events for helpful comments and reflections.

2 Michael Marten, Attempting to Bring the Gospel Home: Scottish Missions to Palestine, 1839-1917 (London: I.B. Tauris, 2006).

3 Marten, Attempting to Bring the Gospel Home, chapters 5 and 6.

4 See for example Brian Stanley, "Church, State, and the Hierarchy of 'Civilization': The Making of the 'Missions and Governments' Report at the World Missionary Conference, Edinburgh 1910," in The Imperial Horizons of British Protestant Missions, 1880-1914, ed. Andrew Porter (Grand Rapids: Eerdmans, 2003), 65, 8o ff. 
the present (e.g. "Humanitarianism is generally understood as assistance that occurs in the context of disasters; consequently, it is most readily applied to emergency relief and post-conflict recovery".5), such language can also be used historically, even if we need to be clear that the framing of such humanitarian work took place in many European missions - and often, certainly, for the Scots-in a setting where "the 'home missions in foreign countries' built the social infrastructure for overseas missions" (as Friedrich, Kaminsky and Löffler put $\left.i^{6}\right)$, rather than as interventions without an existing basis for engagement in a local area. This context is important when thinking about a broader definition such as Barnett's: as will become apparent here, humanitarianism and infrastructure are closely related.

Given that the Scots had been involved in Palestine for a considerable period prior to World War I (and indeed, elsewhere in the Middle East, with missions in Syria, Egypt and South Arabia (now Yemen), ${ }^{7}$ for example), it is important to summarize understandings of the missionary purpose and work in that time. Missionaries throughout the pre-wwI era had long engaged in broader socially-oriented work, centred on the key aspects of education and medicine, though their motivation for this was complex. Both forms of engagement were carried out in and for themselves, almost always with suitably qualified individuals (particularly notable in terms of medicine, where the growing professionalization of medicine in Europe in the mid-late 19th century also ensured the professionalization of medical missionary work). However, both methods can also be seen as a direct response to the overwhelming failure, especially in the Middle East, of the attempts to convert people directly through preaching and confrontation. Most of these missions had minimal success in achieving any significant number of converts, with such conversions as there were being mostly from Latin or Orthodox Christian traditions to Scottish Presbyterianism-no significant conversions of Muslims or Jews were ever recorded. ${ }^{8}$ This led to missionaries approaching these target populations

5 Michael Barnett, The International Humanitarian Order (London: Routledge, 2010), 2.

6 From the preface: Norbert Friedrich, Uwe Kaminsky, and Roland Löffler, The Social Dimension of Christian Missions in the Middle East: Historical Studies of the 19th and 2oth Centuries (Stuttgart: Franz Steiner Verlag, 2010), 8.

7 In Marten, Attempting to Bring the Gospel Home, I discuss the former two mission fields, on South Arabia, see James McLaren Ritchie, The Church of Scotland South Arabia Mission 18851978: A Historical and Critical Evaluation of the Mission founded by Hon. Ion Keith Falconer (Stoke-on-Trent: Tentmaker, 2006).

8 An interesting side effect of this is that such converts were regarded with some suspicion in wider missionary circles, as noted in Brian Stanley, "Defining the Boundaries of Christen- 
more indirectly, in part hoping that "converted" Christians would then go out and convert Muslims and Jews, though this was also a largely ineffective tactic.

\section{$2 \quad$ Education}

Education was the first of the additional methods employed by the churches in their missionary activity. ${ }^{9}$ Scottish education was highly regarded and the Jewish Mission Committees, in seeking to expand their influence, sought to use education from an early stage. In Palestine, the northern missions in Tiberias and Safad had educational and medical facilities (in Safad, medicine was later dropped), but one of the most important forays into education by Jewish missions was Jaffa's Tabeetha School, bequeathed to the Church of Scotland and the United Free Church of Scotland in 1911. After the war, this was developed and run as a joint effort by the Women's Jewish Mission Committees of the two churches (it could be said that this was a pioneering collaboration heralding the 1929 union between the two churches). ${ }^{10}$

Ottoman policy as pursued by Sultan Abdülhamid II emphasized the Islamic nature of his position in order to encourage the loyalty of his Arab notables, thereby seeking to ensure the power of Western states was kept within limited confines in the core regions of his empire. Through the various aspects of tanzimat reform, he encouraged, amongst other things, the creation of new professional schools and teacher training facilities. Although the later years of his reign saw ever-increasing censorship emerge, which to a certain extent impinged on education," it was understood that a populace able to compete with Western states was needed, and that both Ottoman and foreign schools could contribute to this. Concessions granted to Western powers for trade by the Ottoman empire included the necessary freedom for religious activity that gave missionary bodies the space within which to operate. The influx of foreign

dom: The Two Worlds of the World Missionary Conference, 1910," in International Bulletin of Missionary Research 30, no. 4 (October 2006): 173.

9 Max Warren, Social History and Christian Mission (London: SCM, 1967). Chapter 5 examines education in mission.

10 I have written about this: "Independent Women Missionaries in the Scottish School in Jaffa, 1918-1936: Identifying Subaltern Narratives," in Interpreting Relief and Welfare Activities in the Middle East, 1800-2005, eds. Nefissa Naguib and Inger Marie Okkenhaug, Social, Economic and Political Studies of the Middle East and Asia 103 (Leiden: Brill, 2008), 107128.

11 William L. Cleveland, A History of the Modern Middle East (Boulder: Westview, 1994), 115116. 
capital in the latter part of the 19th century ${ }^{12}$ of necessity reduced Ottoman control of some areas of public life; religious practice and education were among the areas where influence was most strongly contested.

The missionaries' educational services can be understood as part of the trend within the Ottoman Empire towards enabling greater participation in an international context dominated by Western European language and culture. For example, although Arabic was specified as the language of instruction to Gwladys Jones before she left for Palestine, she was also told that "Hebrew and English shall both be taught as languages"13 — the latter the language of the dominant imperial power and the former the language of the hoped-forconverts and putative self-governing individuals. Equally, the educators also extended their reach beyond the confines of the school curriculum into the private sphere: Nancy Stockdale cites Walker-Arnott, writing in 188o, before her school became part of the Scottish churches' missions, describing a pupil "actively altering her home environment as a result of her mission education". ${ }^{4}$ The children, it was hoped, would become an active influence on the parents, ultimately leading them to Christian belief. ${ }^{15}$ In that sense the prohibitions on schooling from various rabbis (in particular) that were regularly reported back to Scotland by the missionaries were seen as a mark of success in reaching the families of the children: surely, they reasoned, rabbis would only seek to limit Jewish children's access to Christian schools if they feared the success of the schools?

As shown by Stockdale, education was seen by the missionaries as offering not only an opportunity to encourage belief in (their version of) Christianity, but was also perceived to be a way of improving the culture and general environment of the people they found themselves amongst: a civilizational process,

12 Donald Quataert, "Part Iv: The Age of Reforms, 1812-1914," in An Economic and Social History of the Ottoman Empire, volume 2: 1600-1914, eds. Halil İnalcik and Donald Quartart (Cambridge: Cambridge University Press, 1994), 770-775 examines the effect of trends in the world economy on the Ottoman empire and includes analysis of the state of Ottoman finances; numerous other economic histories of the Ottoman Empire describe this in other ways.

13 United Free Church of Scotland, Women's Jewish Mission Committee (October 11, 1912).

14 Nancy Stockdale, "Gender and Colonialism in Palestine 180o-1948: Encounters among English, Arab and Jewish Women" (PhD diss., University of California Santa Barbara, 2000), 187 .

15 In connection with Anglican schools, "education work tended to foster a desire to join the church of the teachers [and this] led to complications later in relations with the Orthodox Church"; Anthony O'Mahony, "Church, State and the Christian Communities and the Holy Places of Palestine," in Christians in the Holy Land, eds. Michael Prior and William Taylor (London: Melisande, 1994), 17. 
in other words. Like the Americans in Syria, Scottish missionaries in Palestine, when pressed, would argue that their purpose was not explicitly the conversion of Ottoman subjects. ${ }^{16}$ Whilst their educational programmes were meant to civilize, they were not explicitly meant to Anglicize the indigenous population ("A gospel neither German nor British but Jewish must be preached to the $\mathrm{Jew}^{\prime \prime 17}$ ) in the way that Macaulay sought to turn children in India into English people "in taste, in opinion, in morals and in intellect"18 even if he could do nothing about their colour and blood (a "mental miscegenation", to use Benedict Anderson's language, Macaulay not seeking to convert the "idolaters" to Christianity, but to Englishness). We can see this reflected also in Ottoman Syria and Mandate Lebanon, ${ }^{19}$ and by extension, we can also see this with the Scottish missions in Palestine. In all of these instances, the missionaries were, of course, convinced of the superiority of their offering: as they saw it, their education was not just responsible for reading and writing, ${ }^{20}$ but included science (a new subject for most schools in Palestine at the time), ${ }^{21}$ "cleanliness"22 and "hygiene", ${ }^{23}$ aspects of domesticity (for girls: housework, knitting and embroidery, for example $)^{24}$ and industrial and agricultural training (for boys: although some fishing took place, further plans were frustrated) ${ }^{25}$ good behaviour (in

16 Selim Deringil, The Well-Protected Domains: Ideology and the Legitimation of Power in the Ottoman Empire, 1876-1909 (London: I.B. Tauris, 1998), 132.

17 United Free Church of Scotland, Monthly Record (1902): 125.

18 Macaulay argued for English education in order that in 30 years time "there will not be a single idolater among the respectable classes in Bengal"; Benedict Anderson, Imagined Communities (London: Verso, 1983; 2nd edition, 1991), 91.

19 See, for example, various essays in Julia Hauser, Christine B. Lindner, and Esther Möller, Entangled Education: Foreign and Local Schools in Ottoman Syria and Mandate Lebanon (19-2oth Centuries) (Beirut Orient-Institut, 2016).

"The children seem quite as sharp as our own. Five years ago not one girl in Tiberias could read, or distinguish between the bottom and the top of a page. Only one native woman in Tiberias knows the alphabet"; this is from a report of a visit to Fenton's school, Free Church of Scotland, Monthly and Missionary Record (June 1891): 172.

W.P. Livingstone, A Galilee Doctor: Being a Sketch of the Career of Dr. D.W. Torrance of Tiberias (London: Hodder \& Stoughton, n.d., prob. 1923), 23 .

22 From Jane Hope Grierson's impressions of the school in 1889, cited by Isobel Goodwin, May You Live to Be 120! The Story of Tabeetha School, Jaffa (Edinburgh: Saint Andrew Press, 2000) (on behalf of Friends of Tabeetha), 42.

23 These were introduced in Tabeetha in 1913 as a course of study, Goodwin, May You Live to Be 120!, 6o.

24 Goodwin, May You Live to Be 120!, 54. Inger Marie Okkenhaug, The Quality of Heroic Living, of High Endeavour and Adventure: Anglican Mission, Women and Education in Palestine, 1888-1948 (Leiden: Brill, 2002) elaborates on domesticity and academic achievement in Mandate-era Anglican schools in her fourth chapter.

Livingstone, A Galilee Doctor, 109. 
the widest sense $\left.{ }^{26}\right)$ : in other words, a holistic and rounded education as an ideal of the best education Scotland could offer:

It should be our aim to set a good example to the people in the art of training the young, and to establish model schools where mental improvement is energetically cultivated, where physical training is not neglected, and where spiritual nurture is sympathetically imparted. ${ }^{27}$

The Ottomans (correctly) perceived there to be a close relationship between the missionaries and their home countries' imperial ambitions and representatives, ${ }^{28}$ and this insidious intrusion of Western thought into Ottoman territories threatened, in the Sultan's view, the future of the existing order far more even than threats of an economic and military nature, which could be dealt with there and then, given sufficient planning and resources. ${ }^{29}$ This explains in part, at least, the problems around obtaining permission for school buildings. Often, ordinary houses were converted for use until such time as more appropriate premises could be obtained or built, but this came in for particularly strong criticism from the Ottomans because it was seen as a more covert means of opening schools. Ottoman concern at the missionaries' impact was undoubtedly justified, but the unwillingness to engage in large-scale con-

26 Livingstone cites a Greek Orthodox priest trying to prevent children from his community attending: "It is better ... that the girls should grow up ignorant and bad than that they should come under the influence of the Protestant women." Whether or not this was actually said is irrelevant in this context: it communicates the Scots' perception of the Greek priest's feelings about the effects their work would have on "his" girls; Livingstone, $A$ Galilee Doctor, 107. On the subsequent page he contrasts the "cheerful, well-ordered activity" of the girls in the Scots' school with their "wild and untrained condition" before their enrolment.

27 United Free Church of Scotland, Monthly Record, 555 .

28 Of course, at times this relationship could also be rather strained: "Missionary effort was by no means an agency of imperialist politics. Often it was opposed to the colonial authorities; pretty well always it put the interests of its converts first. Yet the success of the Lord was a function of imperialist advance." Eric Hobsbawm, The Age of Empire, 1875-1914 (London: Weidenfeld \& Nicolson, 1987), 71. A necessary correction, reflecting imperialistic patterns of thought, would be that the missionaries always put their perception of "the interests of ... [the] converts first".

29 Deringil, The Well-Protected Domains, 112; also: "by the 189os the missionaries had come to be regarded by the sultan as 'the most dangerous enemies to social order', among all the foreigners living in his domains" (114) because not "only did the missionaries undermine the efforts the Ottomans were making to legitimize the basis of their rule at home, they also proved influential in creating adverse conditions abroad by feeding the Western press with anti-Turkish sentiment" (113). 
flict with the European powers over this issue meant that although occasional harassment took place, the missionaries were relatively free to pursue their aims. ${ }^{30}$

In all of this, however, we should not overplay the missionaries' contribution to the issue of wider education, which was much smaller than that of the wider Ottoman state: although it is easy when examining missions to assume that large numbers of (Jewish, Christian, and Muslim) children passed through their schools and were therefore given a Western education that stood in competition to Ottoman establishments, Ottoman educational efforts under the aegis of the tanzimat reforms were undoubtedly more effective at reaching the majority of children - the missionaries, after all, could only afford to work in a limited number of localities, and central though these may often have been (major cities such as Jerusalem, Beirut, and Cairo, or important towns such as Aleppo, Tiberias, or Jaffa), there were far more Ottoman than missionary schools in the empire as a whole, and their influence was correspondingly greater, even if the quality of some of the schools was rather questionable. ${ }^{31}$ Where Ottoman and missionary schools competed, the hostility could be intense, with both sides using war-like language. ${ }^{32}$ Viewed from a historical perspective at least, the Ottoman aim of creating an educated middle-class that could later take the empire forward as the global context developed was fulfilled, whether they attended Ottoman or missionary schools, with those attending the latter mostly remaining within their existing communities and continuing to be loyal subjects.

In summary then, missionary educational efforts, although meeting resistance from the Ottoman state, were seen by the Scots-in common with many other Western missions - as a way for the missionaries to improve their relationship to the local population and gain inroads, via the children, to the families and communities of the area, particularly as the confrontational model was generally so unsuccessful in this regard.

30 Deringil, The Well-Protected Domains, 117-119.

31 Deringil, The Well-Protected Domains, 132-133.

32 Deringil, The Well-Protected Domains, 133-134 cites the war-like language of Ottoman offcials. The language used by Scottish missionaries in many contexts resembled that of a military campaign - the frequent references to "occupying territory" and such like come to mind here (this use of language was typical of most Western missionaries). 
The second main model used to gain converts aside from direct confrontation was medicine. For the Scottish church missionaries it was in Tiberias and Safad in the $188 \mathrm{os}$, and several years later in Hebron, that medicine was fully exploited as a missionary approach.

In general terms it can be argued that from the perspective of missionary organizations, medical missions served (at least) three clear purposes: (a) they were a way of straightforwardly assisting people in need; (b) they resonated with the donating public who could easily witness the direct benefit to the target population of the funds they were giving; and (c) they provided a "lever" with which to gain access to a target population that might otherwise be reticent to allow access to missionaries-Andrew Walls quotes Herbert Lankaster of the CMs: "It was as heavy artillery that medical missions were used above all: in the less responsive fields, in Islamic societies, and above all in China". ${ }^{33}$ Walls' analysis of the development of medical missions in turn highlights four distinct factors: the imitative (direct obedience to Jesus, who healed people and commanded his disciples to do likewise), the humanitarian/philanthropic (a broad understanding of the "need" to assist the less well off), the utilitarian (preserving the health of the missionaries themselves), and the strategic ("the acceptability of medical missions when no other form of mission could gain a hearing"). ${ }^{34}$ We can see all of these markers reflected in the work in Tiberias, in different ways. For example, even at the very beginning of his career in Tiberias, Dr David Torrance wrote about his need for quality medicines, stating that, amongst other things, he was "anxious to make a good impression from the beginning, so as to gain the confidence of my patients at least". ${ }^{35}$ Occasional concern was expressed about the amount of medical work, and that this might create problems to the detriment of mission's work as a whole. ${ }^{36}$ Seen in this way, the strategic angle became self-defeating, as the means (medical care) took up so much time that the ends (preaching the gospel and creating con-

33 Andrew F. Walls, “'The Heavy Artillery of the Missionary Army': The Domestic Importance of the Nineteenth-Century Medical Missonary," in The Church and Healing, ed. W.J. Shiels (Oxford: Ecclesiastical History Society, 1982), 290.

34 Walls, "'Heavy Artillery of the Missionary Army', 288.

35 Free Church of Scotland, Monthly and Missionary Record (April 1, 1886): 105.

36 Walls, “The Heavy Artillery of the Missionary Army'," 292-294 expounds on the everexpanding investment required once a medical mission had been started. Even though in the 184 os the Committee may have known of only few examples on which to base such an assumption, it would have been obvious to them that the ongoing cost of medicines and equipment would be a financial burden. 
verts) became impossible to implement, or were in some way restricted, as this summary of speeches by Gustav Dalman of Leipzig held in Glasgow and Edinburgh indicates:

The value of medical missions is unquestionable, but perhaps their methods might be improved. The multitudes in the dispensary, to be seen and prescribed for by the doctor within certain hours, make spiritual work for him practically impossible. This is left, therefore, mainly to assistants ... [which] is not quite satisfactory. A Christian physician dwelling among the Jews, visiting their sick, the friend of their homes, the help of their poor, would find many doors open to him, and splendid openings for individual spiritual work. The annual number of cases might be less, but numbers here are of little importance. It would surely be a good principle for medical missions - fewer cases, more visiting of the sick, more individual work, not only by assistants, but by the medical missionary himself. ${ }^{37}$

However, the Scottish missionaries saw this differently. Whilst Torrance might have complained of overwork in the hospital (understandable given he was the main doctor, with, at times, 2,ooo patients being treated each month ${ }^{38}$ ), there are no records of him turning patients away (quite the contrary, he appears to have attempted to resolve every medical case he came across ${ }^{39}$ ), and whilst he was unhappy about the lack of opportunity afforded him to engage more with the population, he argued this highlighted the need for additional staff to share the medical cases and make more time for teaching and preaching. ${ }^{40}$ In addition, this argument, notable for its division between the "spiritual" and the "material", would not have been persuasive for Torrance and the like, who argued that missionary work consisted of a way of life as well as what was taught: i.e. by caring unreservedly for the sick, they saw themselves as living

37 United Free Church of Scotland, Monthly Record (1902): 125. Dalman had once applied to work in the Free Church of Scotland Galilee mission.

38 Ewing writing in Livingstone, A Galilee Doctor, 208.

39 Livingstone, $A$ Galilee Doctor, 217: "If the work is worth doing, it is worth doing well. No quack work in medical work.' But when faced with the tragedy of suffering in the mass ... what course could he adopt? He either had to ... turn away, or do what he could ... to ease their pain. He was too sympathetic to take the sterner course."- the quotation is from an address Torrance gave.

40 Overwhelmed by patients from both sides of the Jordan, he also (in September 1908) suggested opening an additional mission station elsewhere, but the funds for this were not available; Livingstone, A Galilee Doctor, 218. 
witnesses to their faith, exactly as the instructions to Torrance had stated when he first went to Palestine: "It should ever be kept in view that these results ['the enlightenment of their minds, the salvation of their souls' etc.] will be most effectively secured when, to the religious instruction communicated, is added the example of a holy and consistent life". ${ }^{41}$ This kind of holistic approach was typical of 19th-century Scottish Evangelicalism, which laid great stress on living a "godly life". We can also see a parallel to the educational approach here:

In addition to transferring medical skill and know-how they wanted to impart to their students a consciousness of the values implied in the exercise of the art, values of intercultural validity: the authentic commitment of those missions' doctors to help others, even at the expense of tremendous personal, career, and financial gain. They themselves were telling examples who showed that the power to do this work lay in a strong personal faith and commitment. ${ }^{42}$

Peter Williams has argued that particularly in Scottish Presbyterianism, the desire to educate was as much a part of the medical mission as the physical healing itself, and that this confluence of Christianity and civilization was an element of evangelization: in other words, the desire "for the erection of a christian civilization"43 - the pattern in relation to the educational model described above is clear here.

It is not always straightforward to clearly assess the extent to which the Scots succeeded in their ambitions in this regard, though the acceptance of converts into institutions with Western-style entrance criteria, such as the Syrian Protestant College in Beirut or institutions in Europe, does offer one measure of success. There certainly are examples of such individuals, one of the most famous being Leon Levison, who left Tiberias for Edinburgh after conversion to Christianity and became involved in the International Hebrew Christian Alliance as well as being for many decades the superintendent of the Edinburgh Jewish Medical Mission; he was eventually knighted, achieving a level of British civil recognition that perhaps even exceeded his impact on the Scottish and

\footnotetext{
41 Free Church of Scotland, Jewish Mission Committee (December 16, 1884).

42 Christoffer H. Grundmann, "The Contribution of Medical Missions: The Intercultural Transfer of Standards and Values," Academic Medicine 66, no. 12 (December 1991): 733.

43 C. Peter Williams, "Healing and Evangelism: The Place of Medicine in Later Victorian Missionary Thinking," in The Church and Healing, ed. W.J. Shiels (Oxford: Ecclesiastical History Society, 1982): 281 .
} 
international ecclesiastical scene. ${ }^{44}$ However, such stellar examples are rare, and the number of converts remained small.

We can see therefore, that whilst these two techniques were deployed, they clearly had ulterior motives, and although generally unsuccessful in generating significant numbers of converts, they were very clearly linked to the attempts to convert Jews, Muslims, and Orthodox Christians to Protestant Christianity.

With the unprecedented devastation of World War One, however, a different ethos emerged that focussed much more on the direct needs of the people concerned and that was theologically underpinned by a different rationale, bound less to the imperative to convert individuals or communities, and more connected to some of the themes that motivated what became the ecumenical movement. Whilst rampant nationalism and a belief in self-righteous divine sanction developed ever more strongly in mainstream circles in Europe after WWI, for some in the churches, especially those engaged in the wider world in missions and/or the ecumenical movement, a slightly different emphasis emerged. This was in part a result of the diminished emphasis placed on the nation-state of the missionaries' home-lands: as Jonathan Ebel has argued, ${ }^{45}$ whilst it was German soldiers who had "Gott mit uns" engraved into their beltbuckles, all sides thought they had God on their side, and it was the inevitable consequence of this not working out equally for all that led to some questioning of the importance of the nation-state altogether. Ellen Fleischmann has argued cogently that missionaries implicitly understood themselves as not so much citizens of a nation-state, but as citizens of the world, or better still, perhaps, as citizens of the world to come. This came about in part by seeing humanitarianism as part of the modernization of the world and therefore as

44 Frederick Levison, Christian and Jew: The Life of Leon Levison, 1881-1936 (Edinburgh: Pentland, 1989); that acceptance into the Western Christian fold could be tenuous is clear from the account of Levison's supposed recanting of his Christian faith when visiting Safad, in which Thomas Steele, one of the Galilee missionaries, played a significant, and apparently, somewhat malevolent role, with adverse consequences for Levison $\left(5^{2-}-54\right)$. Steele, recently arrived, had not known Levison personally, and reported the "recantation" on the basis of hearsay. The biographer, especially considering he is writing about his own family, generously notes (53): "That Mr Steele was a sick man who had to come home after only a year at Tiberias may have affected his attitude."

45 Jonathan Ebel, "War," in Encyclopedia of Missions and Missionaries, ed. Jonathan Bonk (New York: Routledge, 2007): 456 . 
part of the modernizing mission that virtually all missionaries of European and North American churches adopted wholesale. In that context, writing about female education, she notes that the contrast to modernity was backwardness: "Every society had its 'backward' women, who varied from place to place, and the source of whose backwardness elicited different explanations. This idea of the atavistic, superstitious woman holding back progress and modernity is a strikingly transnational idea"46 that was replicated in capitalist, socialist, and colonial contexts, and that in missionary and other contexts was also clearly linked to racism. ${ }^{47}$ It was also linked to class, of course: "The 'backward, traditional' woman to be modernized was recognizably lower or working class ..."48 and this elicited a common transnational response in humanitarian terms through the promotion of home economics as a way of redeeming and modernizing such women (though, as Fleischmann points out, regardless of whether the context was capitalist, socialist or colonial, the modernizing of domestic labour was inherently conservative in that it still "reinforced ... the gendered division of labour"49).

Humanitarianism took on new meaning in the wake of the crises that engulfed many former colonial areas after wwi. The demise of the Ottoman Empire and the creation of European mandates were just part of the transformation of many areas and populations, from the widespread transfers of Greek and Turkish populations from what became, respectively, solidly Turkish and Greek states, to the Armenian genocide, to the creation of Syria, Lebanon, Jordan, Iraq and Palestine, to the gradual and painful independence of Egyptand so on.

Throughout this time, Scottish involvement in the region continued, to a greater or lesser extent. Towards the end of the war, Scottish missionaries were heavily involved in the Syria and Palestine Relief Fund (SPRF), an ecumenical body to which both the United Free Church of Scotland and the Church of Scot-

46 Ellen Fleischmann, "At Home in the World: Globalizing Domesticity through Home Economics in the Interwar Years," in Transnational and Historical Perspectives on Global Health, Welfare and Humanitarianism, eds. Ellen Fleischmann, Sonya Grypma, Michael Marten, and Inger Marie Okkenhaug (Kristiansand: Portal, 2013), 173.

47 A considerable body of work exists examining racism in missionary contexts. I have discussed this in relation to Palestine (Marten, Attempting to Bring the Gospel Home, chapter 4 and 5), but for a more general overview based on language usage, see e.g. Brian Stanley, "From 'the Poor Heathen' to 'the Glory and Honour of All Nations': Vocabularies of Race and Custom in Protestant Missions, 1844-1928," International Bulletin of Missionary Research 34, no. 1 (January 2010): 3-10.

48 Fleischmann, "At Home in the World," 175.

49 Fleischmann, "At Home in the World," 180. 
land had contributed, and which was dealing with most of the British churches' efforts to provide relief in the region during the war. The churches participated in relief efforts, which given the geopious sentiment around the occupation of Palestine by General Allenby and all that that might herald for Jews, seemed to raise substantial sums: there are records of $£ 25,600$ being raised in the "War Fund". ${ }^{50}$ Staff served in many different areas during and immediately after the war: for example, Dr Alexander Paterson of the Hebron hospital was appointed a Lieutenant in the Royal Army Medical Corps and served in various localities in Britain before being sent to Egypt and then on to Hebron as Principal Medical Officer under the Occupied Enemy Territory Administration; he was then connected to the afore-mentioned SPRF. ${ }^{51}$ Paterson's long-standing lack of interest in directly generating conversions from Jews or Muslims points to his greater interest in providing a social service which on the side offered the opportunity to evangelize (I have argued in the past that he perhaps saw his medical services as less of a tool of conversion or means of access than other missionaries ${ }^{52}$ ). In addition to this, when he did speak of conversion, he was quite adamant that although his work was overseen by a Jewish mission committee, he was serving (and hoping to reach) Jews as well as Muslims, as he stated in his first address to the church's General Assembly. This became the pattern much more in the post-WWI era, and the SPRF was a good avenue for such work: in 1919 the Church of Scotland's General Assembly was told by "distributing food and clothing, by medical relief, by its care of orphans, and in countless other ways, the Fund has given practical illustration of the teaching of Christ to all, irrespective of race or creed." ${ }^{\prime 53}$ It was, however, closed the following year, its "purpose having been accomplished"54_in this regard, what was meant was that the more normal work of the missions could resume, and there was perceived to be less of a need for emergency relief work. Humanitarianism once again became more closely connected to the existing institutions and the ostensible desire to achieve converts to Protestantism. However, after WWI, a new challenge became ever more apparent to the missionaries in the form of Zionism.

\footnotetext{
$50 \quad$ Livingstone, $A$ Galilee Doctor, 252.

51 United Free Church of Scotland, Jewish Mission Committee (March 16, 1915); William Ewing, Paterson of Hebron: "The Hakim" of Missionary Life in the Mountain of Judah (London, n.d. prob. 1925), 155-161.

$5^{2}$ Marten, Attempting to Bring the Gospel Home, see in particular 99-109.

53 Church of Scotland, Jewish Mission Committee Report (1919): 228.

54 Church of Scotland, Jewish Mission Committee Report (1920): 251.
} 
In Palestine, the concern for humanitarian involvement became centred around a question of competition: the United Free Church of Scotland Jewish Mission Committee debate in 1921 recorded that: "The Zionists were throwing no small energy into their schools and hospitals, and by so doing challenged mission schools in the standard of teaching and general equipment. The same was true of their hospitals". ${ }^{55}$ This, it was argued, necessitated clear competitive approaches in order to ensure that the missions were successful in the face of such difficulties:

A situation of this nature compelled the members of the Committee to re-think the policy of the Church in Palestine. It would be wrong to dissipate men [sic] or means in directions which promised a poor result, either by reason of the paucity of Jews [in that area], or by reason of such conditions of work as gave the missionary faint promise of effective service. And, second, whatever agency, educational or medical the Church employed must be of the first efficiency; it would be simple waste otherwise. Unless school and hospital be equipped up to the limit of scientific modern equipment, the work of either would be futile. ${ }^{56}$

This was emphasized in many subsequent years: for example, in 1922, the Assembly was told the Zionists' "avowed purpose" was "to make both Christian school and hospital superfluous so far as the Jew is concerned", ${ }^{57}$ and in 1923 it was noted that, "Aggressive Zionism in both school and hospital emphasized the need for the work in both directions being of first-class quality". ${ }^{58}$ And so it went on, year after year. In 1929, at the last Assembly of the United Free Church before the bulk of it reunited with the Church of Scotland, there was again a heartfelt plea for funds to help support the mission in the face of all these challenges it faced. ${ }^{59}$ There was a fine line being walked here: on the one hand the church needed to communicate to its supporters the need for ongoing support and engagement in the work, recognizing that many members would have themselves experienced ever-improving educational and medical facilit-

55 United Free Church of Scotland, General Assembly Jewish Mission Committee, Proceedings and Debates (1921): 84 .

56 Ibid. 85 .

57 United Free Church of Scotland, General Assembly Jewish Mission Committee, Proceedings and Debates (1922): 86.

58 United Free Church of Scotland, General Assembly Jewish Mission Committee, Proceedings and Debates (1923): 76 .

59 United Free Church of Scotland, General Assembly Jewish Mission Committee, Proceedings and Debates (1929): 102. 
ies at home and would expect this to be replicated by the missions in what were perceived to be less advanced contexts such as Palestine, whilst on the other, it was important for them to convey a need to invest further in the existing work as many of the Zionist facilities would have been created by Jews educated in the West able to replicate standards they had grown to expect there-and this emphasis on modernity came at a considerable financial cost for the United Free Church of Scotland, of course.

With the 1929 union of the United Free and the Church of Scotland, ${ }^{60}$ however, these emphases began to change slightly. The Church of Scotland had had only limited engagement in Palestine prior to the union, primarily through a joint administration by the Women's Jewish Mission Committee of Tabeetha School in Jaffa, which was run with the United Free Church of Scotland's parallel committee. The changed emphases were substantially contingent upon the context in Palestine. In the 193 o Report, for example, a reference to the 1929 riots was followed by noting that,

over $£ 200$ was remitted to [the] Safad and Tiberias [mission stations] to provide food and clothing, and at these and other centres our workers acted as agents for other organisations, such as the Hebrew Christian Alliance and the British Red Crescent Society, to alleviate the sufferings of those who were affected by the outbreak. ${ }^{61}$

This sentiment was motivated in substantial measure by staff on the ground: for example, Rev. Samuel Hanna Semple, the Principal of the Scots College in Safad, wrote in his mission station report that year that whilst the riots were regrettable, "it seemed to be our duty to refrain from partisanship and to confine our energies to the relief of distress wherever we found it". ${ }^{62}$ The following year, this lack of partisanship in offering relief was given as the reason the College had been able to open properly again so quickly: "The unselfish and exacting labours of Mr. and Mrs. Semple in relieving distress to Jew and Arab alike for long after the riots, and their fairness to all parties, left their mark on the people".63 Such work took place against the backdrop of severe global economic depression, of course, ${ }^{64}$ and whilst this had an effect on the Middle East too, it was not felt as acutely in Palestine as in the Western context, including

6o The union resulted in the new body simply being known as the Church of Scotland.

61 Church of Scotland, Jewish Mission Committee Report (1930): 872.

62 Ibid. 908.

63 Church of Scotland, Jewish Mission Committee Report (1931): 853 .

64 Church of Scotland, Jewish Mission Committee Report (1932): 785 . 
in ecclesiastical donor circles. ${ }^{65}$ The coinciding of the Palestine political crisis that necessitated involvement in relief work with the economic depression meant that achieving substantial donations and support from congregations and members was simply more of a challenge for the Church of Scotland.

The next few years mention little in the way of direct emergency humanitarianism, though the Scots' self-perception of their work in encouraging progress and development in relation to modernity is offered regularly: noting the illustrious onward study of many graduates of the Scots College, for example, it was apparent that the "Scots College is playing a large part in training the future leaders of the country"66 — though even in the following year, it was necessary to admit that there were ever fewer posts in government available for such students. ${ }^{67}$ This highlighted a growing problem for the graduating students, one that would only ever really be satisfactorily addressed by the church's Tabeetha School in Jaffa well after the creation of the state of Israel.

There were droughts and floods in these years, with a corresponding impact on the missions' facilities, especially given that many of the people that the Scots most closely related to were involved in the agricultural economy. The missions, under the direction of the Jewish Mission Committee and the Women's Jewish Mission Committee, generally sought to do what they could, though school numbers declined as some parents' ability to support their children's education diminished; some accommodation of this problem occurred, but the missions were always pressed for resources. However, it is with the beginnings of the 1936-1939 Arab Revolt that we can see a significant change occurring: in the 1937 Assembly papers, the strikes are mentioned primarily in relation to reduced involvement by all in the work of the missions, whether educational or medical - though no other critique or engagement occurs that year, perhaps in the expectation that the Revolt would not last. ${ }^{68}$ In 1938, as tensions continued, the only direct mention of the Revolt is the treatment of a British soldier in Tiberias and tensions between "brigands" and over 1,000 troops, ${ }^{69}$ though the report also discusses the future of the Peel Report, which the British government had initiated hoping it would bring peace to the country by proposing the separation of Palestine into two states, Arab and Jewish. ${ }^{70}$ In the May 1939 Church of Scotland General Assembly Report, with World War II

\footnotetext{
65 Ilan Pappe, The Modern Middle East (Abingdon: Routledge, 2005), 43-45.

66 Church of Scotland, Jewish Mission Committee Report (1932): 791.

67 Church of Scotland, Jewish Mission Committee Report (1933): 729 .

68 Church of Scotland, Jewish Mission Committee Report (1937): 863-865.

69 Church of Scotland, Jewish Mission Committee Report (1938): 741.

70 Ibid. $73^{2-733 .}$
} 
just a few months away, the poverty and "general deterioration in the decencies of life" are bemoaned, but not directly attributed to the political unrest in the country, ${ }^{71}$ which is mentioned but briefly in the report, and blamed for travel restrictions and more, ${ }^{72}$ however, this comes across as more of a troublesome inconvenience, rather than a seismic shift in the power dynamics in Palestine.

\section{5}

Conclusions

This essay's brief portrayal of Church of Scotland public statements highlights several changes in direction for the missions, whilst noting the contingent nature of such changes. There are several direct conclusions that can be drawn in relation to the wider context.

Firstly, during World War I and the immediate aftermath, substantial relief efforts were organized, mostly ecumenically - this was a direct form of humanitarian relief, perhaps most obviously directly linked to the definition by Michael Barnett noted above.

Secondly, during the 1920s, although the United Free Church of Scotland worked at providing some measure of relief to those in need, it continually sought to defend the Church against the perceived influence of Zionism. This, then, was a form of humanitarianism, but one that reflected pre-World War I understandings of education and medicine as tools in the desire to achieve missionary aims, coupled with direct competition (in the church's eyes) with the ambitions of the Zionist movement. This was not uncomplicated, as there was also a certain admiration by the Scots of the Zionist colonizers and their advances in agriculture and economy, a position that understood the bringing of European modernity to Palestine-it was simply that the missionaries would have preferred the local Palestinian population to have adopted their version of European modernity, rather than that of the Zionists.

Thirdly, with the global depression and the uniting of the two churches, occasional mentions are made of relief and humanitarian work, particularly at the Scots College, but interest in this kind of work diminishes, even though the need is there. Whilst it is possible to see the passing of the Tiberias mission founder David Torrance (1923) and retiral shortly thereafter of Alexander Paterson from Hebron - two of the longest-serving male missionaries in Palestine-as perhaps playing a role here, we can also point to a parallel to

71 Church of Scotland, Jewish Mission Committee Report (1939): 704.

72 Ibid. $702-703$. 
the work of Maria Småberg in describing the Anglican approach to the British authorities as an "ambiguous friendship", ${ }^{73}$ and this, to some extent, describes also what is happening for the Scots. Småberg argues that there was a continual co-operation with the governmental authorities on the part of the Anglicans, and we can argue similarly for the Scots: it is no coincidence that the new St Andrews Memorial Church in Jerusalem was the "home" for many Scots who served the British government's Mandate authority in Jerusalem. The need, therefore, to provide full humanitarian services diminishes somewhat as the Scots' own government was governing the country and providing services to many. Cynics might argue that Scottish provision was therefore reduced to simply supplementing the work of government, and mostly in Palestinian Arab areas, as the Zionist movement offered such substantial services to the Jewish population.

Finally, with the Arab Revolt, we can see again the desire to offer some relief where possible, though there is little recognition of the significance of the wider political and social changes heralded by the growing influence of Zionism and the response in the form of the Arab Revolt. However, the apparent thinning of support for humanitarian work in Palestine by the late 1930s is not to be dismissed out of hand: in fact, we could say that there was increasing recognition of the need for support and help-just not necessarily where the mission stations were located, and not in Palestine. The key to this understanding is to be found in the opening of the 1939 Jewish Mission Committee Report to the Church of Scotland's General Assembly, which discusses the persecution of Jews world-wide, particularly by the Nazi regime in Germany:

Beyond all anticipation of what persecution in its recklessness might do, the worst of perils ever dreamed of has been surpassed, and such an avalanche of trouble has swept over the Jewish people that the Church's relation to them can no longer be thought of as simply the relation of a Christian missionary Church to a non-Christian people, but as the relation of the Church to a great political, racial, and humanitarian problem. ${ }^{74}$

The report does, in typically—for that time-anti-Semitic fashion, ${ }^{75}$ go on to blame "the Jews" for their "stubborn" nature in being unwilling to become

73 Maria Småberg, Ambivalent Friendship-Anglican Conflict Handling and Education for Peace in Jerusalem, 1920-1948 (Lund: Lund University Press, 2005).

74 Church of Scotland, Jewish Mission Committee Report (1939): 691.

75 This was part of a long tradition of virulent anti-Semitism in Jewish mission circles, as noted, for example, in Marten, Attempting to Bring the Gospel Home, 136 and elsewhere. 
Christian, but despite this, it does clearly enunciate a serious concern for Jews well beyond Palestine. Being overwhelmed by the news coming out of continental Europe and wanting to help Jews there-for example, in their Budapest and other European missions - the Jewish Mission Committee had to restrict the level of support they could offer in Palestine, a priority that was reflected in their annual General Assembly Report, one of the primary mechanisms for communicating their work and intentions to the wider Church. This undoubtedly had negative effects on the Church's missions' engagement with local Jewish-Arab relations in Palestine-but within months, all of this would be beyond the control of the Church of Scotland as it and Britain as a whole were overwhelmed by the outbreak of World War II. Zionist terrorism in Palestine in support of the creation of a Jewish state during and immediately after World War Two, the Zionist-Arab war, and the devastating impact of the Nakba just three short years later, had catastrophic humanitarian effects for the Palestinian Arab population that the churches-including the Church of Scotland—struggled to deal with. ${ }^{76}$ By this time, however, wider global humanitarian understandings had emerged in the context of the postWorld War Two settlement, the creation of the United Nations and its agencies (including UNHCR, UNRWA, and the WHO), the development of new understandings of human rights and refugee priorities - and the churches' involvement in the Palestinian refugee crisis was proportionately rather minimal when compared to the work carried out by these new international agencies.

\section{Bibliography}

\section{Church of Scotland}

Church of Scotland. Jewish Mission Committee Report (1919). Church of Scotland. Jewish Mission Committee Report (1920). Church of Scotland. Jewish Mission Committee Report (1930). Church of Scotland. Jewish Mission Committee Report (1931). Church of Scotland. Jewish Mission Committee Report (1932). Church of Scotland. Jewish Mission Committee Report (1933). Church of Scotland. Jewish Mission Committee Report (1937).

76 For a brief overview of post-World War II context, see Michael Marten, "Indigenisation and Contextualisation-The Example of Anglican and Presbyterian Churches in the Holy Land," in Christianity and Jerusalem: Theology and Politics in the Holy Land, ed. Anthony O'Mahony (London: Gracewing Publishers, 2005), 115-137. 
Church of Scotland. Jewish Mission Committee Report (1938).

Church of Scotland. Jewish Mission Committee Report (1939).

\section{Free Church of Scotland}

Free Church of Scotland. Jewish Mission Committee (December 12, 1884).

Free Church of Scotland. Monthly and Missionary Record (April 1, 1886).

Free Church of Scotland. Monthly and Missionary Record (June 1891).

\section{United Free Church of Scotland}

United Free Church of Scotland. Monthly Record (1902).

United Free Church of Scotland. Women's Jewish Mission Committee (October 11, 1912).

United Free Church of Scotland. Jewish Mission Committee (March 16, 1915).

United Free Church of Scotland. General Assembly Jewish Mission Committee, Proceedings and Debates (1921).

United Free Church of Scotland. General Assembly Jewish Mission Committee, Proceedings and Debates (1922).

United Free Church of Scotland. General Assembly Jewish Mission Committee, Proceedings and Debates (1923).

United Free Church of Scotland. General Assembly Jewish Mission Committee, Proceedings and Debates (1929).

\section{Books, Chapters, and Articles}

Anderson, Benedict. Imagined Communities. London: Verso, 1983; 2nd edition, 1991.

Barnett, Michael. The International Humanitarian Order. London: Routledge, 2010.

Cleveland, William L. A History of the Modern Middle East. Boulder: Westview, 1994.

Deringil, Selim. The Well-Protected Domains: Ideology and the Legitimation of Power in the Ottoman Empire, 1876-19o9. London: I.B. Tauris, 1998.

Ebel, Jonathan. "War." In Encyclopedia of missions and missionaries, edited by Jonathan Bonk, 453-458. New York: Routledge, 2007.

Ewing, William. Paterson of Hebron: "The Hakim" of Missionary Life in the Mountain of Judah. London, n.d., prob. 1925.

Fleischmann, Ellen. "At Home in the World: Globalizing Domesticity through Home Economics in the Interwar Years." In Transnational and Historical Perspectives on Global Health, Welfare and Humanitarianism, edited by Ellen Fleischmann, Sonya Grypma, Michael Marten, and Inger Marie Okkenhaug, 158-181. Kristiansand: Portal, 2013.

Friedrich, Norbert, Uwe Kaminsky, and Roland Löffler. The Social Dimension of Christian Missions in the Middle East: Historical Studies of the 19th and 2oth Centuries. Stuttgart: Franz Steiner Verlag, 2010. 
Goodwin, Isobel. May You Live to Be 120! The Story of Tabeetha School, Jaffa. Edinburgh: Saint Andrew Press, 2000. On behalf of Friends of Tabeetha.

Grundmann, Christoffer H. "The Contribution of Medical Missions: The Intercultural Transfer of Standards and Values." Academic Medicine 66, no. 12 (December 1991): $731-733$.

Hauser, Julia, Christine B. Lindner, and Esther Möller. Entangled Education: Foreign and Local Schools in Ottoman Syria and Mandate Lebanon (19-2oth Centuries). Beirut: Orient-Institut, 2016.

Hobsbawm, Eric. The Age of Empire, 1875-1914. London: Weidenfeld \& Nicolson, 1987. Levison, Frederick. Christian and Jew: The Life of Leon Levison, 1881-1936. Edinburgh: Pentland, 1989.

Livingstone, W.P. A Galilee Doctor: Being a Sketch of the Career of Dr. D.W. Torrance of Tiberias. London: Hodder \& Stoughton, n.d. prob. 1923.

Marten, Michael. "Indigenisation and Contextualisation-The Example of Anglican and Presbyterian Churches in the Holy Land." In Christianity and Jerusalem: Theology and Politics in the Holy Land, edited by Anthony O'Mahony, 115-137. London: Gracewing Publishers, 2005.

Marten, Michael. Attempting to Bring the Gospel Home: Scottish Missions to Palestine, 1839-1917. London: I.B. Tauris, 2006.

Marten, Michael. "Independent Women Missionaries in the Scottish School in Jaffa, 1918-1936: Identifying Subaltern Narratives." In Interpreting Relief and Welfare Activities in the Middle East: 1800-2005, edited by Nefissa Naguib and Inger Marie Okkenhaug, 107-128. Social, Economic and Political Studies of the Middle East and Asia 103. Leiden: Brill, 2008.

McLaren Ritchie, James. The Church of Scotland South Arabia Mission 1885-1978: A Historical and Critical Evaluation of the Mission founded by Hon. Ion Keith Falconer. Stoke-on-Trent: Tentmaker, 2006.

Okkenhaug, Inger Marie. The Quality of Heroic Living, of High Endeavour and Adventure: Anglican Mission, Women and Education in Palestine, 1888-1948. Leiden: Brill, 2002.

O'Mahony, Anthony. "Church, State and the Christian Communities and the Holy Places of Palestine." In Christians in the Holy Land, edited by Michael Prior and William Taylor, 11-27. London: Melisande, 1994.

Pappe, Ilan. The Modern Middle East. Abingdon: Routledge, 2005.

Quataert, Donald. "Part IV: The Age of Reforms, 1812-1914." In An Economic and Social History of the Ottoman Empire, volume 2:1600-1914, edited by Halil İnalcik and Donald Quartart, 770-775. Cambridge: Cambridge University Press, 1994.

Småberg, Maria. Ambivalent Friendship - Anglican Conflict Handling and Education for Peace in Jerusalem, 1920-1948. Lund: Lund University Press, 2005.

Stanley, Brian. “Church, State, and the Hierarchy of 'Civilization': The Making of the 'Missions and Governments' Report at the World Missionary Conference, Edinburgh 
1910." In The Imperial Horizons of British Protestant Missions, 1880-1914, edited by Andrew Porter. Grand Rapids: Eerdmans, 2003.

Stanley, Brian. "Defining the Boundaries of Christendom: The Two Worlds of the World Missionary Conference, 1910." In International Bulletin of Missionary Research 3o, no. 4 (October 2006): 171-176.

Stanley, Brian. "From 'the Poor Heathen' to 'the Glory and Honour of All Nations': Vocabularies of Race and Custom in Protestant Missions, 1844-1928." International Bulletin of Missionary Research 34, no. 1 (January 2010).

Stockdale, Nancy. "Gender and Colonialism in Palestine 180o-1948: Encounters among English, Arab and Jewish Women." PhD diss., University of California Santa Barbara, 2000.

Walls, Andrew F. “'The Heavy Artillery of the Missionary Army': The Domestic Importance of the Nineteenth-Century Medical Missionary." In The Church and Healing, edited by W.J. Shiels, 287-297. Oxford: Ecclesiastical History Society, 1982.

Warren, Max. Social History and Christian Mission. London: sсм, 1967.

Williams, C. Peter. "Healing and Evangelism: The Place of Medicine in Later Victorian Missionary Thinking." In The Church and Healing, edited by W.J. Shiels, 271-285. Oxford: Ecclesiastical History Society, 1982. 